\title{
$7 \quad$ Intelligence sharing among coalition forces
}

\author{
Some legal and ethical challenges \\ and potential solutions
}

\author{
David Letts
}

\section{Introduction}

Since the end of World War II there have been numerous examples of coalition operations involving two or more military forces, including some operations that have been held under the authority of the United Nations through the passing of a UN Security Council Resolution. ${ }^{1}$ Other types of multinational operations, comprising both formal alliances that are set up under treaty arrangements, such as NATO, ${ }^{2}$ and more informal coalitions that are typically established under ad hoc arrangements that deal with a specific issue or incident, such as the International Maritime Security Construct, ${ }^{3}$ have been a feature of military operations for centuries. ${ }^{4}$ Changes in the structure of alliances and coalitions have also been a regular occurrence, often driven by changes that occur in the political landscape of one or more partner State. There are also other types of cooperation that occur between military forces, such as routine participation in exercises and training activities, as well as exchange of personnel, staff meetings and high-level discussions between senior officials. Overall, these activities are all examples of two or more foreign militaries working together to achieve a common objective.

An integral aspect of these coalition operations is the collection, pooling and sharing of intelligence between the forces of the coalition states involved and such sharing often represents an indispensable element of the effective conduct of these operations. However, intelligence sharing among coalition forces can raise difficult questions of domestic and international laws. This is especially true in situations where one State contributes intelligence to a combined operational pool that is then used by all of the coalition partners as they pursue their individual goals. In such situations, there may be differences in legal and ethical perspectives on the use of the pooled intelligence even among liberal democratic states.

This chapter will initially identify what is meant by the term "intelligence" and then outline some of the mechanisms used by states to collate and pool their intelligence resources. The next part of the chapter will review two recent case studies where coalition states have relied on intelligence to undertake military operations and assess the implications that arise from these cases. The case studies will be supported by consideration of some hypothetical scenarios that illustrate the problems that arise for other coalition partners in circumstances where there is some

DOI: $10.4324 / 9781003164197-10$ 


\section{David Letts}

possibility that an operational partner state may use pooled intelligence to undertake an activity that does not correspond with the legal obligations that apply to the "providing" state.

Why is this analysis being undertaken? Reviewing some of the challenges involved in sharing intelligence among coalition partners can help to identify where the legal and ethical risks lie for coalition states so that conscious decisions regarding intelligence sharing can be included in the working methodology of shared intelligence agencies and the planning of such operations. The chapter will conclude with some suggestions that coalition states may want to consider so that concerns regarding the legal issues that arise from intelligence sharing between states can be adequately addressed.

\section{What is "intelligence" and how is it used?}

The collection of information to assist military commanders discharge their duties has been an element of warfare for as long as battles between opposing forces have been held. One way of describing the concept of intelligence is the approach used by the RAND Corporation who note that "military intelligence includes information on other countries' military forces, plans, and operations gained through a variety of collection methods" (RAND Corporation n.d.). In its simplest form, the term "intelligence" refers to "information concerning an enemy or an area" that is then available for a commander to use (Watson n.d.). These days, collection of intelligence occurs from a wide variety of sources, including "satellites, ultramodern aircraft, electronic systems, human sources, cameras, imaging and electronic devices, and a host of other systems" which all combine so that information collection can be now undertaken on a scale that was not previously achievable (Watson n.d.).

The pooling and sharing of intelligence between the forces of states involved in a coalition is also a common feature of modern military operations, and this shared material is usually indispensable for the effective conduct of these operations. There are different methods used to establish intelligence sharing networks, with perhaps the most famous (or infamous?) being the "Five Eyes" network that is established under the UKUSA Agreement of 1946. ${ }^{5}$ The Five Eyes network originally only included the United Kingdom and the United States of America but by 1956 it had been expanded to include Canada, Australia and New Zealand. ${ }^{6}$

Other states have more recently established military intelligence sharing agreements but the volatility that can impact inter-state relations has meant that some of these arrangements have not been without a certain level of difficulty. For example, in August 2019 it was reported that the South Korean government had decided to give the necessary three months' notice that the 2016 military intelligence agreement between Japan and South Korea would not be renewed due to "ongoing tensions over wartime history and trade". ${ }^{7}$ However, at the last minute in November 2019 it was announced that a solution had been reached between the two states that allowed the agreement to be renewed "six hours before the agreement was to expire" (Tong-hyung 2019). 
Another way in which intelligence is shared between states is through the creation of pooled resource centres, and again these may, or may not, be part of a formal alliance structure. An example of intelligence sharing as part of a formal alliance is the NATO Intelligence Fusion Centre (NIFC) that has been operating in the United Kingdom since December 2007 (NIFC n.d.). The NIFC's website identifies its mission as being the provision of "intelligence to warn of potential crisis and the support the planning and execution of NATO operations". ${ }^{8}$ More recently, in 2017 NATO reformed its headquarters organization by establishing a Joint Intelligence and Security Division with a mission to "initiate a broad series of reforms to improve the quality and utility of intelligence provided to NATO's most senior political and military leaders" (von Loringhoven 2019).

Intelligence centres that operate with pooled resources may also be focused on specific issues, and can be constructed in separate and distinct ways. Three examples of this occurring in the maritime domain are:

- The Singapore Information Fusion Centre (IFC) which is a permanent arrangement that was established in 2009 to provide regional maritime domain awareness and is hosted by the Republic of Singapore Navy. The IFC uses a network of International Liaison Officers (ILOs) from a range of different countries that collect open-source information in order to compile a range of products that contribute to maritime domain awareness in the IFC's area of interest (IFC 2019b). The IFC holds a "Shared Awareness Meeting" approximately every six months where information is provided regarding maritime security incidents that have occurred in the region during the previous six-month period. At the time of writing, 24 different states have contributed ILOs since the IFC's inception. ${ }^{9}$

- Combined Maritime Forces (CMF), which operates as a partnership of approximately 30 states at any one time, has three discrete missions related to maritime security in the middle east region: CTF 150 Maritime Security (outside the Gulf), CTF 151 Counter-Piracy and CTF 152 Gulf Maritime Security (CMF 2020). CMF's website describes the organization as a "coalition of the willing and does not proscribe a specific level of participation from any member nation" (CMF 2020). Nevertheless, CMF does have a headquarters in Bahrain where intelligence is shared - at least in the form of maritime domain awareness - and the CMF hosts a regular Shared Awareness and Deconfliction (SHADE) conference where senior officials can discuss maritime issues and threats in CMF's area of operations. ${ }^{10}$

- The relatively open reporting and sharing of information that occurs with the IFC and CMF can be contrasted with United Kingdom Maritime Trade Operations (UKMTO), "a Royal Navy capability with the principal purpose of providing an information conduit between military which (includes/security forces) and the wider international maritime trade" (UKTMO n.d.). In relation to sharing information, UKMTO declares that it "shares relevant information with appropriate authorities within states in the region. All information received is strictly controlled in a secure information system and 
recognises that the source and content of the information is often extremely sensitive" (UKTMO n.d.).

This section of the chapter has shown that intelligence can be collected and shared in a number of different ways, and these methods will vary according to the manner in which a coalition has been established and the type of intelligence being collated. In the case of the "Five Eyes", the intention behind that coalition has always been to collect sensitive and highly classified intelligence, while other intelligence collection centres, such as the IFC in Singapore, are constructed to receive and disseminate open-source intelligence.

Regardless of whether intelligence being collected is open source or highly classified, the potential legal and ethical risks associated with its dissemination to, and use by, coalition partners should be properly understood. The next part of the chapter will examine some case studies to illustrate the problem.

\section{Coalition operations - two case studies}

Many military operations that have taken place in the past few decades have been characterized by the involvement of coalition forces: the 1999 NATO intervention in Serbia and subsequent deployment of peacekeeping forces in Kosovo; Afghanistan after 2001; Iraq after 2003, including operations against the Islamic State (ISIS) since 2010; the 2011 intervention in Libya; recent Saudi-led airstrikes in Yemen; and even the activities of the Combined Maritime Forces off the east coast of Africa and in the Gulf region that was mentioned in the previous section.

The previous sections of this chapter have identified that intelligence sharing in coalition operations, regardless of whether or not the laws of armed conflict apply, is now a regular and expected feature of these activities. However, in recent years there have also been numerous reported instances of intelligence sharing being one of the key reasons why states have engaged in conduct that has subsequently proved to be wrongful - or at least, perhaps, regrettable. Examples that will be briefly examined in this section of the chapter are the Iraq War in 2003 and the recently released Report of the Government Inquiry into Operation Burnham and related matters (Arnold 2020). In both of these incidents, intelligence available to the coalition forces played a key role for at least part of the legal justification that was provided for the operation. The issue that arises for consideration in this chapter is whether there is a resultant legal and ethical risk that intelligence provided by one coalition partner could be, or was, misused by another coalition partner to commit a violation of international law.

\section{Iraq War 2003}

Much has been written regarding the use of intelligence to inform the decisionmaking that preceded the entry of coalition forces into Iraq in 2003 and there are plenty of opinions about whether or not the use of military force at that time was legal from a jus ad bellum perspective. ${ }^{11}$ However, assessing that question is not 
the purpose of using this period as a case study in this chapter. Rather, the purpose is to make some remarks about the key pieces of intelligence that coalition forces relied upon, and assess whether legal consequences arise.

The central legal document relevant to this present assessment is United Nations Security Council (UNSC) Resolution 1441 which was adopted by a unanimous vote of $15-0$ on November 8, 2002 (UNSCR n.d.). It is not necessary to delve too deeply into the text of UNSCR 1441 for this chapter, other than to mention the critical concept that is directly relevant to the intelligence assessment regarding Iraq, namely that it "has been and remains in material breach of its obligations under relevant resolutions". Contentious arguments were then subsequently raised in relation to who had the legal authority to decide that military action should take place as a result of these "material breaches" but again, this question is beyond the present scope. ${ }^{12}$

In order to authorize military action, clearly there needed to be an assessment of whether sufficient evidence to support the claims of material breach existed. It is this point that provides the area of most concern for the topic of this chapter, as it has been noted that during "Security Council debates during the conflict, China, France, Germany and Russia were all unsatisfied that the US and UK allegations about Iraq's weapons of mass destruction and support for terrorism had been substantiated" (Anton 2013). The primary reason for this dissatisfaction, of course, is that the United States and the United Kingdom (and Australia) did not share the intelligence that they supposedly relied upon in forming the opinion that military action against Iraq was necessary under one of the legal bases that were provided at the time. ${ }^{13}$ Additionally, it is noted that subsequent to the cessation of coalition military action in Iraq, it was found that neither weapons of mass destruction were held by Saddam's regime nor were the supposed close terrorist links with Al-Qaeda ever proved.

\section{The New Zealand Defence Force (NZDF) in Afghanistan: Operation Burnham}

The second case study to briefly consider is Operation Burnham which was a New Zealand Special Air Service operation that took place in Afghanistan in August 2010. The reason this case study has been chosen is that it involved, inter alia, allegations that faulty intelligence had been used during the operation and this criticism, and others, were subject to a detailed and lengthy inquiry with the result being that publicly available information can be reviewed (Arnold 2020). The purpose of the inquiry was to examine a number of "allegations of wrongdoing by NZDF forces" during the operation including the killing of civilians in violation of the law of armed conflict, deliberate destruction of civilian houses and an alleged "cover-up" by the NZDF (Arnold 2020, 7-8).

As far as the purpose of this chapter is concerned, a number of aspects of the Operation Burnham Report are relevant. ${ }^{14}$ First, the Report contains a detailed analysis of the intelligence assessment that was relied upon to undertake the NZ Special Forces' raid that was the subject of the inquiry. The report's assessment 
of the intelligence raised by, and shared with, the NZDF was that it was largely accurate and could be reasonably relied upon (Arnold 2020, 189, 197). Next, the Report addresses the situation of NZDF being aware of the possibility that handing over a detainee to Afghan authorities may result in that person being tortured (i.e. that the NZDF had intelligence to that effect) and then looks at the issues that arise. The Report stated that:

the core obligations fall into three broad categories: preventive obligations, conduct obligations and response obligations. States need to do all they can to prevent torture, not commit it or be complicit in it, not return or transfer people to places where they face a real risk of torture, and respond swiftly and effectively if torture may have, or has, occurred.

(Arnold 2020, 302)

The final point regarding the Report is its conclusion that significant mistakes were made by the NZDF in relation to events that took place while the force was deployed to Afghanistan, including a failure to adequately deal with the transfer of a detainee to Afghan custody despite a real risk of torture existing. Additionally, "NZDF and other New Zealand agencies did not respond as they should have when they learnt of the possibility that he had been tortured" (Arnold 2020, 385).

The salient point from this case study is that intelligence can be used, or misused, in a variety of ways. In a situation like that faced by the NZDF on operations in Afghanistan the collection and use of shared intelligence to inform a combat mission was found to be quite appropriate. However, the Report also found that there was a lack of adequate action taken in relation to credible intelligence that a detainee was likely to be tortured and that proper consideration of that likelihood created a legal responsibility to prevent the detainee's transfer to Afghan authorities in those circumstances (Arnold 2020, 315-16). The potential consequences that arise from such transfers will be dealt with later.

\section{The applicable legal frameworks}

The legal framework governing intelligence sharing among coalition partners can be influenced by a number of overlapping regimes and comment regarding the main legal frameworks will now be provided.

\section{The law of state responsibility}

Under the general international law principle of state responsibility, states can be responsible for internationally wrongful conduct attributable to them, normally because such conduct is committed by the state's own organs and agents. ${ }^{15} \mathrm{~A}$ number of rules, however, allow for state responsibility to arise in connection to the wrongful act of another state. The most relevant of these rules in relation to sharing intelligence among coalition partners is codified in Article 16 of the 
International Law Commission's (ILC) Draft Articles on Responsibility of States for Internationally Wrongful Acts (ASRs):

\section{Aid or assistance in the commission of an internationally wrongful act}

A State which aids or assists another State in the commission of an internationally wrongful act by the latter is internationally responsible for doing so if:

(a) that State does so with knowledge of the circumstances of the internationally wrongful act; and

(b) the act would be internationally wrongful if committed by that State (International Law Commission 2001a, 65)

This rule, however, is subject to a number of limiting elements, as explained by the ILC's commentary:

Article 16 limits the scope of responsibility for aid or assistance in three ways. First, the relevant State organ or agency providing aid or assistance must be aware of the circumstances making the conduct of the assisted State internationally wrongful; secondly, the aid or assistance must be given with a view to facilitating the commission of that act, and must actually do so; and thirdly, the completed act must be such that it would have been wrongful had it been committed by the assisting State itself.

(International Law Commission 2001b, 66)

Of particular relevance here are the requirements of knowledge by the assisting state and the parity of obligations on the part of the assisting and the assisted state, both of which are more complex than it might appear at first glance. Similarly, the scope of the rule appears to be limited to aid and assistance provided by one state to another, and therefore if that approach is taken it would not apply to assistance provided by states to non-state actors. However, in the Bosnian Genocide case the International Court of Justice not only affirmed the customary status of Article 16 but also applied it by analogy to assistance provided by a state to a non-state actor, albeit in the specific context of state responsibility for complicity in relation to the crime of genocide. ${ }^{16}$

Therefore, despite some questions regarding limitations, which exist about the breadth of Article 16's scope, there is potential for coalition states to be attributed some level of responsibility for aiding or assisting a third state's internationally wrongful act through the provision of intelligence. While normally the assisting state would only be responsible for its own (now wrongful) act of providing assistance, it may also be that in some cases the assisting state will share in the responsibility of the assisted state for committing the principal wrong.

\section{Responsibility of international organizations}

In addition to state responsibility, the possibility also exists that if a coalition military operation takes place under the umbrella of an international organization, 
such as the UN or NATO, the organization itself might accrue responsibility as an international legal person for aiding and assisting a state or another organization in the commission of an internationally wrongful act. The provision of intelligence, that was then used to enable a violation of international law, could easily assist with the commission of such an act. However, the ICJ has made it clear that any such responsibility for an organization will not be of a criminal nature, but arises as a matter of its "obligations and responsibilities under international law". 17

Further, in 2011 the ILC concluded its project on the responsibility of international organizations and Article 14 of the ILC's draft articles is an equivalent rule to Article 16 in the articles on state responsibility (International Law Commission 2011). Whether the ILC's work accurately reflects customary law is a difficult question, but in any case there is support for considering that "the notion of the responsibility of international organizations presupposes, naturally, that international organizations are considered separate actors in their own right, with their own legal personality and moral agency" (Klabbers 2017, 1136). One obvious difficulty in attributing responsibility to international organizations is that they are not normally parties to the relevant International Humanitarian Law (IHL) and human rights treaties, thus requiring an exploration of whether they are bound by similar obligations under customary international law - a task that is, unfortunately, beyond the scope of this chapter.

\section{International Humanitarian Law}

While IHL ${ }^{18}$ does not specifically regulate the collection or sharing of intelligence, it does impose some primary obligations on states with respect to the conduct of other states. These primary rules operate in addition to the secondary rules of state responsibility under general international law. Most importantly, under Common Article 1 of the four Geneva Conventions of 1949, all "High Contracting Parties undertake to respect and to ensure respect for the present Convention in all circumstances". ${ }^{19}$

In the words of the authoritative Pictet Commentary of 1960, Article 1 of Geneva Convention (III), this overarching obligation:

applies to the respect of each individual State for the Convention, but that is not all: in the event of a Power failing to fulfil its obligations, each of the other Contracting Parties (neutral, allied or enemy) should endeavour to bring it back to an attitude of respect for the Convention. The proper working of the system of protection provided by the Convention demands in fact that the States which are parties to it should not be content merely to apply its provisions themselves, but should do everything in their power to ensure that it is respected universally.

Parallel obligations exist under customary IHL. For example, Rule 139 of the ICRC Customary IHL Study provides that "[e]ach party to the conflict must respect and ensure respect for international humanitarian law by its armed forces 
and other persons or groups acting in fact on its instructions, or under its direction or control" (ICRC n.d.). Rule 144 stipulates that "States may not encourage violations of international humanitarian law by parties to an armed conflict. They must exert their influence, to the degree possible, to stop violations of international humanitarian law" (ICRC n.d.).

It is therefore at the very least arguable that a state which shares intelligence with another state (and possibly a non-state actor) in the course of a coalition military operation can violate these rules. If that state does so in the knowledge that the other state (or non-state actor) is engaged in serious violations of IHL, such as war crimes, or that there is real risk that such violations might occur, then legal responsibility would arise.

\section{International human rights law}

The applicability of human rights treaties extraterritorially and in times of armed conflict is a matter of both complexity and controversy. Judicial authority and academic literature on the topic are voluminous and somewhat confusing. It is however beyond dispute that there is an increasing trend towards applying human rights law to such situations, and it seems unlikely that this trend will reverse itself in the future. Some partners in coalition military operations, such as the United States and Australia, are subjected to less exacting scrutiny of their compliance with the relevant human rights treaties than other states, such as those in Europe or the United Kingdom, which have accepted the compulsory jurisdiction of the European Court of Human Rights (ECtHR) ${ }^{20}$ Even so, because of the close relationships of cooperation in coalition operations, it is inevitable that the increased level of scrutiny by the ECtHR will have ripple effects even on non-European coalition partner states.

Importantly, just like the Geneva Conventions, human rights treaties impose both negative and positive obligations on states' party. These obligations not only require respect for the provisions themselves, but also oblige states to ensure they are not complicit in violations by third parties, as well as exercising due diligence to prevent and suppress violations by third parties against individuals within the state's jurisdiction. Close scrutiny of the way in which states have met these obligations has occurred, and one recent example is the Report into Detainee Mistreatment and Rendition 2001-2010 released by the United Kingdom's Intelligence and Security Committee of Parliament in 2018. In relation to intelligence sharing, the Report found that British "Agencies shared an unprecedented amount of intelligence with foreign liaison services to facilitate the capture of detainees ... [but] . . the Agencies failed to consider whether it was appropriate to pass intelligence where mistreatment of detainees was known or reasonably suspected" (Grieve 2018, 3).

Scrutiny of the outcome from intelligence sharing is only likely to escalate as more information enters the public domain via freedom of information requests, publication of information on the internet, formal public inquiry processes like the UK inquiry mentioned earlier, and through the cross-referencing and linking of different sets of national information releases that analysis of the compiled 
data permits. Similarly, intelligence operations generally have been subjected to increased public scrutiny after the "Snowden revelations" of the electronic surveillance capabilities of agencies such as the National Security Agency (NSA) and Government Communications Headquarters (GCHQ) were made public in 2014 (BBC News 2014). This has in turn provoked much litigation, as well as important activities within the UN system, including the adoption of a number of resolutions on the right to privacy in the digital age by the UN General Assembly. ${ }^{21}$

It is simply inevitable that intelligence sharing in coalition military operations will increasingly become a live issue before both domestic courts and international institutions applying human rights law. Accordingly, some serious thinking is required to understand how human rights standards might apply to such extraordinary situations, beyond simply rejecting their applicability outright - a strategy that has been previously known to backfire.

\section{Other areas of uncertainty}

Legal uncertainty can arise due to other legal regimes that could potentially impact on partner use of shared intelligence. For example, international or domestic criminal law could be relevant if lethal targeting operations are conducted by a coalition partner following the provision of shared intelligence. Again using the United Kingdom as an example, in 2016 the UK Parliament's Joint Committee on Human Rights examined the "Government's policy on the use of drones for targeted killing" (Joint Committee on Human Rights 2016). Issues that were canvassed by the Committee included assessing whether "those involved in implementing the Government's policy ... are ... running the risk of criminal prosecution for murder or complicity in murder" (Joint Committee on Human Rights 2016, 24). The Committee had particular concern about the provision of intelligence to a partner that then prosecutes a lethal strike against an individual whose status as a lawful military target under the applicable legal regime is contested. The Committee noted that the:

possibility of criminal prosecution for complicity in murder also arises for all those UK personnel who have a role in assisting or facilitating the use of lethal force by coalition allies, such as the US, which has a much wider approach to the use of lethal force outside of armed conflict. Such assistance might take the form of logistical support (for example, permitting US jets to use UK airbases), or the provision of intelligence about targets gathered by UK surveillance and reconnaissance.

(Joint Committee on Human Rights 2016, 24)

It should also be noted that while a potential charge of complicity could be a matter of individual criminal responsibility at the micro level, it could also elevate to state responsibility for an internationally wrongful act at the macro level.

Uncertainty as to the status of an individual could also arise due to differing national legal interpretations on the issues of civilians taking a direct part 
in hostilities. ${ }^{22}$ For example, in Australia's case, membership of an organized armed group could be enough to warrant the lethal targeting of an individual in a non-international armed conflict. ${ }^{23}$ However, a coalition partner may not have the same legal opinion, and therefore sharing intelligence with Australian forces may lead to a kinetic operation resulting in the death of an individual where the legality of that death is not agreed. A further risk potentially arises for those states that are party to the International Criminal Court. ${ }^{24}$

\section{Potential solutions}

The potential legal issues associated with intelligence sharing are many and varied, so it is not possible to provide a simple, cohesive set of solutions that would cover every conceivable eventuality. Rather, it is necessary to contemplate how a few selected initiatives might contribute to overcoming the challenges that are created by the issues identified in this chapter.

One step along the way has already occurred with the creation of the Five Eyes Intelligence Oversight and Review Council (FIORC) in 2017. The FIORC has the stated aim, inter alia, of creating a forum where Council members can:

exchange views on subjects of mutual interest and concern, compare best practices in review and oversight methodology, explore areas where cooperation on reviews and the sharing of results is permitted where appropriate, encourage transparency to the largest extent possible to enhance public trust; and maintain contact with political offices, oversight and review committees, and non-Five Eyes countries as appropriate.

(Five Eyes Intelligence Oversight and Review Council 2017)

The fact that this Council exists at all, in an area that is notoriously reluctant to shed too much light on its activities, is testament to the progress that has been made in recent years towards transparency and accountability in relation to intelligence activities.

Other potential solutions include the production of guidelines and policy recommendations for organizations such as NATO and its partner state armed forces that would enable them to engage in effective intelligence sharing in the modern battlespace, while ensuring that this is done in compliance with applicable legal frameworks. These guidelines should result in simplifying the decision-making processes for the military legal advisers and their operational commanders, which would go a long way towards improving legal certainty and providing improved situational awareness and intelligence analysis. This, in turn, should result in better operational outcomes for those involved in coalition operations.

A final point here is to note the role played by various civil society interest groups and the press who routinely subject the activities of armed forces to rigorous scrutiny. There have been many occasions when reports of violations of applicable legal standards have emerged through the work of such interest groups and the press and it is not expected that any change in the focus of these entities will 


\section{David Letts}

occur. In fact, the important oversight function of external bodies was explicitly recognized in the Operation Burnham Report as being able to "provide a platform to enhance public understanding of complex legal and operational issues, and to identify good (or bad) practice in a fair, independent and impartial manner" (Arnold 2020, 370). The Report observed that military forces can be unable to do this without external assistance due to:

what we regard as failings of culture at the upper echelons of NZDF - confirmation bias, lack of objectivity and rigour in scrutinising "facts", unnecessary defensiveness coupled with an unwillingness to acknowledge error, failure to follow up inconvenient information, and non-compliance with the disciplines and obligations inherent in the principles of ministerial control of the military and ministerial responsibility to Parliament.

(Arnold 2020, 379)

This criticism is not just applicable to the NZDF; it can easily be applied to other military forces when assessing their response to allegations of unlawful activity.

\section{Conclusion}

Intelligence sharing by coalition forces is a necessary element of many activities undertaken by modern military forces. Coalition operations may be increasingly frequent in a polycentric international order in which no single state is dominant. The use of intelligence can not only provide coalition forces with a distinct battlespace advantage but also raise legal and ethical questions for states and military commanders if shared intelligence is used in a manner that is inconsistent with a range of existing legal obligations that reflect different ethical perspectives. This chapter has described how issues can arise even among liberal democracies with a common political and ethical heritage. Even more pressing concerns will arise in coalitions comprised of states with more diverse sets of values.

Clarifying the applicable legal frameworks that accompany sharing of intelligence is a task that needs further work, and achieving this will help to delineate between what is permissible and those practices that are prohibited, as well as outline any zones of constructive ambiguity. This chapter has attempted to highlight some of the legal considerations that apply to intelligence sharing by coalition partners. It is really only a starting point on a journey, however, that has many miles yet to run. States and their armed forces, the United Nations and other international organizations such as NATO must devote sufficient attention to the topic in order to foster the detailed academic and military consideration that is needed to satisfactorily address the issue in a satisfactory way.

\section{Postscript}

The impetus for writing on this topic originated from a paper produced by The Royal Institute of International Affairs (Chatham House) in November $2016^{25}$ and 
a subsequent Workshop on Intelligence Sharing in Multinational Military Operations that was convened at the University of Nottingham in January $2018 .^{26}$ The author is very grateful to all those involved in both of these activities for their valuable and thoughtful contributions, but responsibility for the opinions in this chapter rests with the author alone.

\section{Notes}

1 An early example is UN Security Council Resolution 84 of June 25, 1950 which authorized military operations in Korea, while a more recent example is UN Security Council Resolution 1973 of March 17, 2011 which inter alia enforced an arms embargo, imposed a no-fly zone and strengthened the sanctions regime in relation to Libya.

2 NATO is formally known as the North Atlantic Treaty Organization and was established in 1949 pursuant to the North Atlantic Treaty 34 UNTS 243.

3 The International Maritime Security Construct (IMSC) is a coalition currently comprising eight nations (Albania, Australia, Bahrain, Kingdom of Saudi Arabia, Lithuania, United Arab Emirates, United Kingdom and United States of America) that was formed in 2019 to support maritime security in the Gulf region. See IMSC Public Affairs (2020) for further details about the IMSC and "Australia Joins International Maritime Security Construct in the Gulf" (n.d.), a press release from the Australian Prime Minister announcing Australia's involvement in the IMSC.

4 In this chapter, the term "coalition operations" will be used for convenience to describe the various types of multinational operations, regardless of whether the states involved are part of a formal alliance or some other more informal coalition; the term "partner operations" can also be sometimes used to describe situations when military forces are working together. One analysis of the distinction that may be drawn between a "coalition" and a "wartime alliance" can be found in Weitsman (2010).

5 Details of the 1946 UKUSA Agreement which was a "top secret, post-war arrangement for sharing intelligence between the United States and the UK" can now be obtained from the UK National Archives after the files that relate to the Agreement were publicly released in June 2010 (The National Archives 2010).

6 Details of the UKUSA agreement were made public in June 2010 after FOI requests were lodged in the UK and the USA (Norton-Taylor 2010).

7 In the period prior to the deadline for the termination of the agreement, calls were made for the two parties to resolve their differences and ensure that the agreement continued to operate (Harold 2019).

8 https://web.archive.org/web/20200128162530/http://web.ifc.bices.org/about.htm

9 See IFC (2019a).

10 The 45th SHADE was held in Bahrain in November 2019 and although the 46th SHADE was scheduled to be held in April 2020, it has been delayed until November 3-5, 2020.

11 Compare, for example, the contrasting positions on this topic taken by O Corten $\mathrm{Y}$ Dinstein (Corten 2010; Dinstein 2011).

12 See generally Simpson (2005) and Iwanek (2010).

13 The two main legal arguments were that action was, in fact, authorized under existing UNSC Resolutions and/or it was necessary to respond in self-defence to the threat posed by Iraq. Previous references to the works of Corten, Dinstein, Simpson, Iwanek and Anton, provide details of critical assessments of the legality of these arguments (Corten 2010; Dinstein 2011; Iwanek 2010; Anton 2013).

14 The Operation Burnham Report comprises 12 Chapters and 2 Appendixes and covers a far greater breadth of topics than is possible, or necessary, to address in this chapter.

15 See generally Rothwell et al. (2014, chap. 8). 
16 Application of the Convention on the Prevention and Punishment of the Crime of Genocide (Bosnia and Herzegovina v. Serbia and Montenegro), Judgment, [2007], ICJ Rep, paras $420-421$.

17 Application of the Convention on the Prevention and Punishment of the Crime of Genocide (Bosnia and Herzegovina v. Serbia and Montenegro), Judgment, [2007], ICJ Rep, para 170.

18 The term International Humanitarian Law (IHL) is widely used, but the body of law it encompasses is also known as the law of armed conflict (LOAC) or the law of war. IHL is sometimes narrowly construed to refer to the law that protects victims of armed conflict. For one explanation of this law, see ICRC (2004).

19 Article 1 is identical in each of the four Geneva Conventions of 1949: Geneva Convention for the Amelioration of the Condition of the Wounded and Sick in Armed Forces in the Field 75 UNTS 31 (GC I); Geneva Convention for the Amelioration of the Condition of Wounded, Sick and Shipwrecked Members of Armed Forces at Sea (GC II) 75 UNTS 85; Geneva Convention Relative to the Treatment of Prisoners of War (GC III) 75 UNTS 135; Geneva Convention Relative to the Protection of Civilian Persons in Times of War (GC IV) 75 UNTS 287.

20 The United Kingdom's departure from the European Union did not result in the UK ceasing to be a member of the European Court of Human Rights (Cowell 2021).

21 UN General Assembly Resolution 71/199, The right to privacy in the digital age, A/ RES/71/199 (December 19, 2016).

22 Agreement on what constitutes "direct participation in hostilities" is widely contested with many states critical of the approach adopted by the ICRC as set out in Melzer (2009). See generally McLaughlin (2019).

23 Clarifying the position for members of the Australian Defence Force, the Criminal Code Amendment (War Crimes) Act 2016 included membership of an organized armed group within the category of what constitutes a lawful target.

24 Rome Statute of the International Criminal Court, July 17, 1998, 2187 UNTS 3.

25 See Moynihan (2016).

26 This Workshop, conducted under the "Chatham House Rule" involved a number of government practitioners, academics and representatives from international organizations and NGOs, was co-organized by the University of Nottingham's International Law and Security Centre and the ANU College of Law's Centre for Military and Security Law.

\section{References}

Anton, Donald K. 2013. "'International Law and the 2003 Invasion of Iraq Revisited', Revised Version of a Paper Delivered on 30 April 2013 at ANU Asia-Pacific College of Diplomacy Seminar". The Invasion of Iraq: Canadian and Australian Perspectives, ANU College of Law Research Paper No. 14-19.

Arnold, Terence. 2020. Report of the Government Inquiry into Operation Burnham and Related Matters. Auckland: New Zealand Government. www.operationburnham. inquiry.govt.nz/assets/IOB-Files/Report-of-the-Government-Inquiry-into-OperationBurnham-print-version.pdf.

"Australia Joins International Maritime Security Construct in the Gulf". n.d. Pm.Gov.Au. Accessed December 16, 2020. www.pm.gov.au/media/australia-joins-internationalmaritime-security-construct-gulf.

BBC News. 2014. "Edward Snowden: Leaks That Exposed US Spy Programme". $B B C$ News, January 17. www.bbc.com/news/world-us-canada-23123964.

CMF. 2020. "Combined Maritime Forces (CMF)". Combined Maritime Forces (CMF). Accessed December 16, 2020. https://combinedmaritimeforces.com/. 
Corten, Olivier. 2010. The Law against War: The Prohibition on the Use of Force in Contemporary International Law. Oxford; Portland, OR: Hart Publishing.

Cowell, Frederick. 2021. "The Brexit Deal Locks the UK into Continued Strasbourg Human Rights Court Membership”. LSE Brexit Reality (blog). Accessed March 20, 2021. https://blogs.lse.ac.uk/brexit/2021/01/17/the-brexit-deal-locks-the-uk-into-continuedstrasbourg-human-rights-court-membership/.

Dinstein, Yoram. 2011. War, Aggression and Self-Defence. 5th edition. New York: Cambridge University Press.

Five Eyes Intelligence Oversight and Review Council. 2017. "Charter of the Five Eyes Intelligence Oversight and Review Council". Accessed December 16, 2020. www.dni. gov/files/ICIG/Documents/Partnerships/FIORC/Signed\%20FIORC\%20Charter\%20 with\%20Line.pdf.

Grieve, Dominic. 2018. Detainee Mistreatment and Rendition: 2001-2010. London: HMSO. https://isc.independent.gov.uk/wp-content/uploads/2021/01/20180628-HC1113-ReportDetainee-Mistreatment-and-Rendition-2001-10.pdf.

Harold, Scott W. 2019. "South Korea Should Consider Sticking with Intelligence-Sharing Pact with Japan”. The RAND Blog (blog). November 5. www.rand.org/blog/2019/11/ south-korea-should-consider-sticking-with-intelligence.html.

ICRC. n.d. "Customary IHL: Rule 139: Respect for International Humanitarian Law". Accessed December 16, 2020. https://ihl-databases.icrc.org/customary-ihl/eng/docs/v1_ rul_rule139.

. n.d. "Customary IHL: Rule 144: Ensuring Respect for International Humanitarian Law Erga Omnes". Accessed December 16, 2020. https://ihl-databases.icrc.org/ customary-ihl/eng/docs/v1_rul_rule144.

2004. "What Is International Humanitarian Law?". Accessed December 16, 2020. www.icrc.org/en/doc/assets/files/other/what_is_ihl.pdf.

IFC. 2019a. "Information Fusion Centre". Accessed December 16, 2020. www.ifc.org.sg/ ifc2web/app_pages/User/common/commonIndexv5.cshtml.

- 2019b. MARSEC Situation in IFC AOI 2019. Singapore: IFC. www.ifc.org.sg/ ifc2web/Publications/Annual\%20Report/2019/AOI\%20Document\%202019.pdf.

IMSC Public Affairs. 2020. "IMSC Holds Virtual Change of Command Ceremony". U.S. Central Command, April 30. Accessed December 16, 2020. www.centcom.mil/MEDIA/ NEWS-ARTICLES/News-Article-View/Article/2176451/imsc-holds-virtual-changeof-command-ceremony/.

International Law Commission. 2001a. Draft Articles on Responsibility of States for Internationally Wrongful Acts, with Commentaries. New York: United Nations. https://legal. un.org/ilc/texts/instruments/english/commentaries/9_6_2001.pdf.

2001b. Year Book of the International Law Commission 2001 Volume II Part Two. New York: United Nations. https://legal.un.org/ilc/publications/yearbooks/english/ ilc_2001_v2_p2.pdf.

2011. Draft Articles on the Responsibility of International Organizations 2011. New York: United Nations. https://legal.un.org/ilc/texts/instruments/english/draft_articles/ 9_11_2011.pdf.

Iwanek, Tomasz. 2010. "The 2003 Invasion of Iraq: How the System Failed". Journal of Conflict and Security Law 15 (1): 89-116. https://doi.org/10.1093/jcsl/krp024.

Joint Committee on Human Rights. 2016. The Government's Policy on the Use of for Targeted Killing: Second Report of Session 2015-16. London: HMSO. https:// publications.parliament.uk/pa/jt201516/jtselect/jtrights/574/574.pdf. 


\section{David Letts}

Klabbers, Jan. 2017. "Reflections on Role Responsibility: The Responsibility of International Organizations for Failing to Act”. European Journal of International Law 28 (4): 1133-61. https://doi.org/10.1093/ejil/chx068.

McLaughlin, R. 2019. "Organised Armed Groups and Direct Participation in Hostilities". In Military Law in Australia, edited by Robin Creyke, Dale Stephens, and Peter Sutherland. Alexandria: The Federation Press.

Melzer, Nils. 2009. Interpretative Guidance on the Notion of Direct Participation in Hostilities under International Humanitarian Law. Geneva: ICRC. www.icrc.org/en/doc/ assets/files/other/icrc-002-0990.pdf.

Moynihan, Harriet. 2016. Aiding and Assisting: Challenges in Armed Conflict and Counterterrorism. Chatham House Report, November 2016. https://www.chathamhouse.org/ sites/default/files/publications/research/2016-11-11-aiding-assisting-challenges-armedconflict-moynihan.pdf.

The National Archives. 2010. "Newly Released GCHQ Files: UKUSA Agreement". The National Archives. Accessed December 16, 2020. www.nationalarchives.gov.uk/ukusa/.

NIFC. n.d. "NATO Intelligence Fusion Centre (NIFC)". Accessed December 16, 2020. http://web.ifc.bices.org/.

Norton-Taylor, Richard. 2010. "Not So Secret: Deal at the Heart of UK-US Intelligence". The Guardian, June 24, sec. US News. www.theguardian.com/world/2010/jun/25/ intelligence-deal-uk-us-released.

RAND Corporation. n.d. "Military Intelligence". Accessed December 16, 2020. www. rand.org/topics/military-intelligence.html.

Rothwell, Donald, Stuart Kaye, Afshin Akhtarkhavari, and Ruth Davis. 2014. International Law: Cases and Materials with Australian Perspectives. 2nd edition. Port Melbourne, VIC, Australia; New York: Cambridge University Press.

Simpson, Gerry. 2005. "The War in Iraq and International Law". Melbourne Journal of International Law 6 (1): 167.

Tong-hyung, Kim. 2019. "South Korea Will Keeps Its Military Intelligence Pact With Japan: For Now". The Diplomat, November 23. https://thediplomat.com/2019/11/southkorea-will-keeps-its-military-intelligence-pact-with-japan-for-now/.

UKTMO. n.d. “About UKMTO”. Accessed December 16, 2020. www.ukmto.org/aboutukmto.

UNSCR. n.d. "Security Council Resolution 1441: UNSCR". Accessed December 16, 2020. http://unscr.com/en/resolutions/1441.

von Loringhoven, Arndt Freytag. 2019. “A New Era for NATO Intelligence”. NATO Review, October 29. www.nato.int/docu/review/articles/2019/10/29/a-new-era-for-natointelligence/index.html.

Watson, Bruce W. n.d. "Intelligence | Military Science". Encyclopedia Britannica. Accessed December 16, 2020. www.britannica.com/topic/intelligence-military.

Weitsman, Patricia. 2010. "Wartime Alliances versus Coalition Warfare: How Institutional Structure Matters in the Multilateral Prosecution of Wars". Strategic Studies Quarterly 4 (January): 29-53. 